\title{
Determination of Geothermal Reservoir Zone of Sorik Marapi, Mandailing Natal, North Sumatra
}

\author{
Muhammad Shofi Hidayatullah ${ }^{1 *}$, Agus Didit Haryanto ${ }^{1}$, Johanes Hutabarat ${ }^{1}$, Ryan Hidayat $^{2}$ \\ ${ }^{1}$ Geological Engineering, Faculty of Geological Engineering, Padjajaran University \\ Bandung Sumedang Main St., Km.21, Jatinangor, Bandung, 45363, Indonesia \\ ${ }^{2}$ Sorik Marapi Geothermal Power, KS-ORKA Renewables Pte Ltd., North Sumatra \\ Recapital Building, 5th Floor, Adityawarman St., Kav 55, Jakarta, 12160, Indonesia \\ *E-mail: m.shofi.h@gmail.com
}

Article received: 18 February 2021, revised: 26 February 2021, accepted: 26 February 2021

DOI: 10.51835/iagij.2021.1.1.24

\begin{abstract}
The Sorik Marapi Geothermal Power (SMGP) Field is located in Mandailing Natal (350 km to the southeast from Medan), North Sumatra. This study needed alteration mineral data validation with fluid geochemical characteristics from surface manifestations, and production wells were determined the geothermal reservoir zone. Therefore geothermometer and geoindicator calculations were used. Laboratory tests were carried out on 38 surface manifestations and 11 cutting samples of exploration well. Manifestations in this area include hot springs, fumaroles, and steaming ground. Alteration minerals found in the study area are anhydrite, epidote, calcite, chlorite, muscovite, pyrophyllite, and zeolite. The alteration zone is located in the zeolite zone, the epidote zone, and the anhydrite-sericite zone. Geochemical manifestations of surface and production wells containing chloride water, sulfate water, sulfate-chloride water, and bicarbonate water. The estimated reservoir temperature of SH-01 well shows temperatures ranging from $240-280^{\circ} \mathrm{C}$, SH- 02 well shows temperatures of $249.89-302.92^{\circ} \mathrm{C}$, SH-03 well show temperatures of $231.09-280^{\circ} \mathrm{C}$. The mineral geothermometer calculation, which is correlated with the geochemical fluid geothermometer, shows valid results. This is evident from the estimated reservoir temperatures of the two geothermometers.
\end{abstract}

Keywords: Sorik Marapi, geothermal, reservoir, geothermometer, geoindicator

\section{INTRODUCTION}

Geothermal energy in Indonesia has enormous potential and holds $40 \%$ of the world's geothermal potential. The potential reserves of 25,300 MW [1], about 2,000 MW, have been successfully developed into electrical energy. The estimated geothermal potential of Sorik Marapi is around 200 MW. Currently, the installed capacity is $20 \mathrm{MW}$ in unit 1 and $30 \mathrm{MW}$ unit 2 [2]. The exploration phase is necessary to increase its potential.

In the development process, geothermal energy requires a potential search activity or what is called exploration. Three fields must be fulfilled in the geothermal exploration process, namely geology, geochemistry, and geophysics [3]. The geology field plays a role in the initial exploration survey, which aims to map the area.

In geothermal exploration, the presence of alteration minerals is the main characteristic of areas that have the potential to be exploited. Therefore, this research is intended to study the relationship between alteration minerals and geochemical characteristics to determine the potential geothermal reservoir zone in the Sorik Marapi area. This is important because the geochemistry of fluids in the geothermal area is useful for reservoir zones. The Sorik 
Marapi reservoir zone is formed from rocks that change composition and structure, showing high-temperature alteration minerals exposed in the process of conversion. The lithology type, level of alteration, and presence of open fractures suggest that the Sorik Marapi volcanic formation is an ideal host for a geothermal reservoir [4].

\section{Regional Geological Setting}

The Tertiary and Quaternary Geological characteristics of Sumatra Island are a manifestation of the tectonic process. The magmatic arc and back-arc basin cut across most of Sumatra's island from North Sumatra to South Sumatra is a dextral horizontal fault known as the Semangko Fault or large Sumatra fault [5]. This horizontal fault was formed due to the interaction between the Indian-Australian plate and the tilted Sunda Microplate. This fault has an important tectonic position because it can be considered as the boundary between the Sunda Microplate and the Indian-Australian plate to the west. The Tertiary tectonic development, which is to the east of the Sumatra fault, also includes the Tertiary tectonic development of the Sunda Microplate [6].

\section{Hydrothermal Alteration}

Hydrothermal alteration is the result of the formation of mineralization due to the flow of hydrothermal solutions. This solution is a liquid with a high temperature, around $100^{\circ} \mathrm{C}$ to $500^{\circ} \mathrm{C}$. It is formed from the remaining cooling of magma, which can change the minerals that have been there before to form certain mineral [7]. The geothermal surface manifestation is an indicator of the subsurface geothermal resource, shown by hot or warm springs, mud pools, fumaroles, and flowing artesian bore.

The Sorik Marapi volcanoes are dominated by andesitic units (Figure 1) in composition with a minor appearance of basaltic rocks. Young lava flows (Tmv) and pyroclastic deposits (Qvsm) emerge from the active Sorik Marapi volcano. Volcanic lava front ends along the Marapi Fault, which traverses NW-SE, and the pyroclastic/volcanic deposits gradually thin out towards the east of this structure. The youngest formations are pyroxene andesite lava rock (Qhvsm) which includes pyroclastic deposits that fill valleys, grabens, and lowland areas consisting of decomposed and fragmented sediments from older rock units.

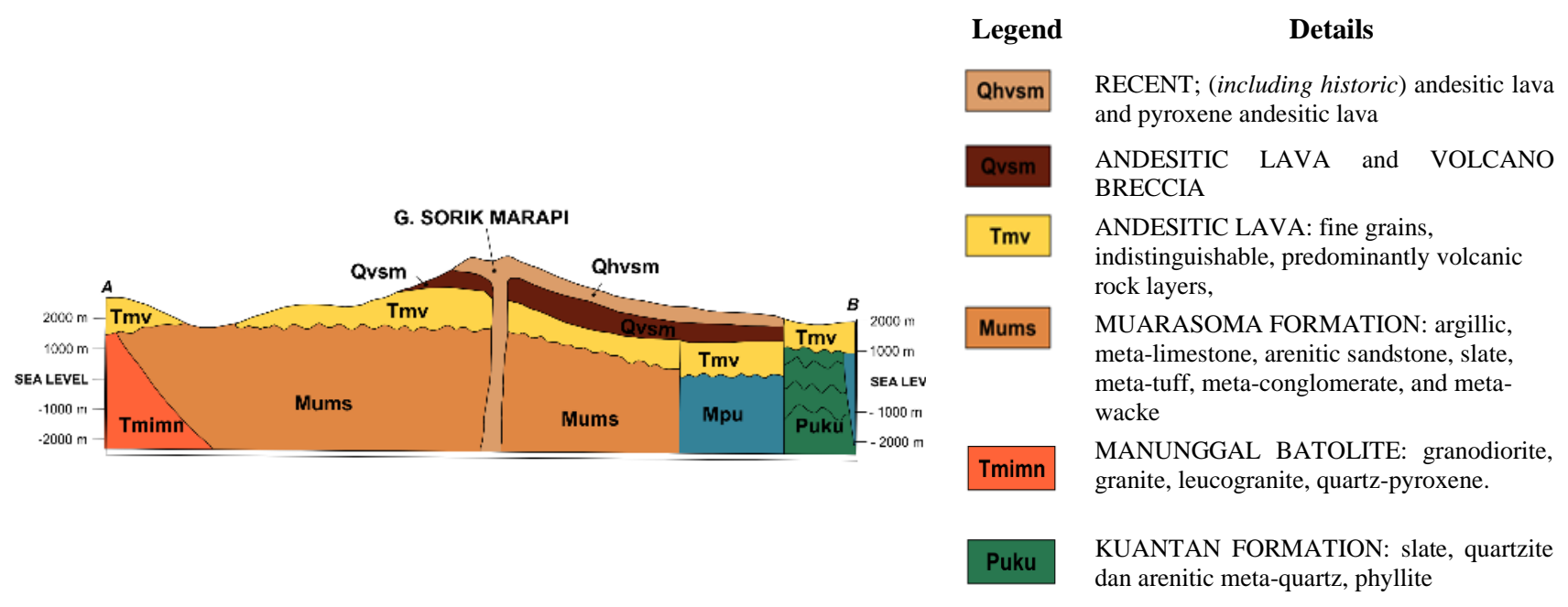

Figure 1. Geological Map Legend of the Study Area (modification from [6]) 


\section{METHODOLOGY}

Primary and secondary mineral descriptions were carried out based on transparent minerals optical properties under the microscope, both on parallel nicol (PPL) and crossed nicol (XPL). The samples used were cutting of 11 samples from wells SH-01, $\mathrm{SH}-02$, and $\mathrm{SH}-03$. The petrographic analysis was carried out, and there were the presences of plagioclase, quartz, pyroxene, k-feldspar, muscovite, secondary quartz, and pyrophyllite minerals.

Geothermal chemical geoindicators can be used for various purposes can be viewed from the $\mathrm{SO}_{4}-\mathrm{HCO}_{3}-\mathrm{Cl}$ geoindicators, Cl-Li$\mathrm{B}$ geoindicators, Na-K-Mg geoindicators, and $\mathrm{N}_{2}-\mathrm{CO}_{2}-\mathrm{Ar}$ geoindicators. These geoindicators were used to determine the type of geothermal fluid, the type of rock that interacts with the fluid and the gas contaminants that affect it. Geoindicators used to predict reservoir temperature refer to the consideration factors for choosing a geothermometer, including the type of surface manifestation in the form of hot water and containing hot water with chloride or bicarbonate water.

Determine the reservoir's quality level, and the equilibrium method is being used for quality control analysis by ion. Ion balance is needed to determine whether the data can be used for further calculations in the geochemical analysis. The relevant data for use have a value of less than $5 \%$. This method can be applied by dividing the elements into two groups, namely anions and cations, then calculating the ratio between positive ions and negative ions by first multiplying them by each element's equivalent weight.

\section{RESULTS AND DISCUSSION \\ Well Lithology \\ Well SH-O1}

In-depth of 277 to $280 \mathrm{~m}$ consisting of lithic tuff rock. Crystal tuff is found in the incision depth of 772 to $775 \mathrm{~m}$. The lithology at a depth of $844 \mathrm{~m}$ is in the form of basaltic andesite and at a depth of $1054 \mathrm{~m}$ is in the form of altered andesite. The petrographic analysis data shows the presence of andesitic rock [8] and volcanic material in the form of tuff, indicating that the lithology in the particular well is generated from volcanic deposits either explosively or effusively.

Effusive eruptions produce andesite and basaltic andesite rocks, which are thought to have undergone magma evolution, resulting in magma composition differences. In contrast, explosive eruptions produce crystal tuffs and lithic tuffs. As a result of hydrothermal fluid, these rocks undergo alteration depending on the fluid's temperature and composition passing through the rock.

\section{Well SH-O2}

The lithology of the $\mathrm{SH}-02$ well is a rock resulting from volcanic deposits in andesite and tuff rocks. Lithology at a depth of 801$804 \mathrm{~m}$ is a lithic tuff. At a depth of 1611$1614 \mathrm{~m}$, andesite-basaltic was found [8] (changed then at a deeper depth altered andesite was located at 2178-2181 m. Repeated volcanic eruptions, both effusive and explosive, produce rocks with various characteristics such as those in this well. Based on the volcanic facies' division concerning the volcanic cone landscape and the associated rock associations [9], both wells are located in the proximal facies with lava lithology, volcanic breccia, and tuff. 


\section{Well SH-03}

The lithology of the SH-03 well is rock resulting from volcanic deposits in andesite rocks [8] and tuff. Lithology at a depth of 333-336 $\mathrm{m}$ in the form of a vitric tuff. At a depth of $807-810 \mathrm{~m}$, altered lithic tuff was found. The primary component partly has changed into secondary components consisting of the mineral chlorite, epidote, calcite, then at a deeper depth altered andesite was found at 1146-1149 m.

\section{Alteration Minerals of Research Area}

The presence of alteration minerals (secondary minerals) can be an indicator of subsurface temperature in a geothermal system. Factors that also influence secondary minerals' formation in hydrothermal systems include temperature, fluid chemistry, fluid concentration, host rock composition, kinetic reactions, equilibrium duration, and permeability [2].

\section{Anhydrite}

Anhydrite $\left[\mathrm{CaSO}_{4}\right]$ (Figure 2) is formed from hydrothermal fluids which have a neutral to acidic $\mathrm{pH}$, with a $\mathrm{pH}$ value of around 5-6 [10]. The temperature of anhydrite formation is 160 to $300^{\circ} \mathrm{C}$. Anhydrite is commonly associated with quartz, illite, adularia, carbonate minerals, biotite, and sericite.

However, mineral association depends on the alteration zone in an area. If there is hydration or the addition of hydrogen cations to the anhydrite and the temperature drops below $120^{\circ} \mathrm{C}$, the anhydrite will be converted into gypsum. The anhydrite (Figure 1) found in the study area microscopically had a size of +/- $0.1 \mathrm{~mm}$. Anhydrite shows a rectangular shape with two-way slits.

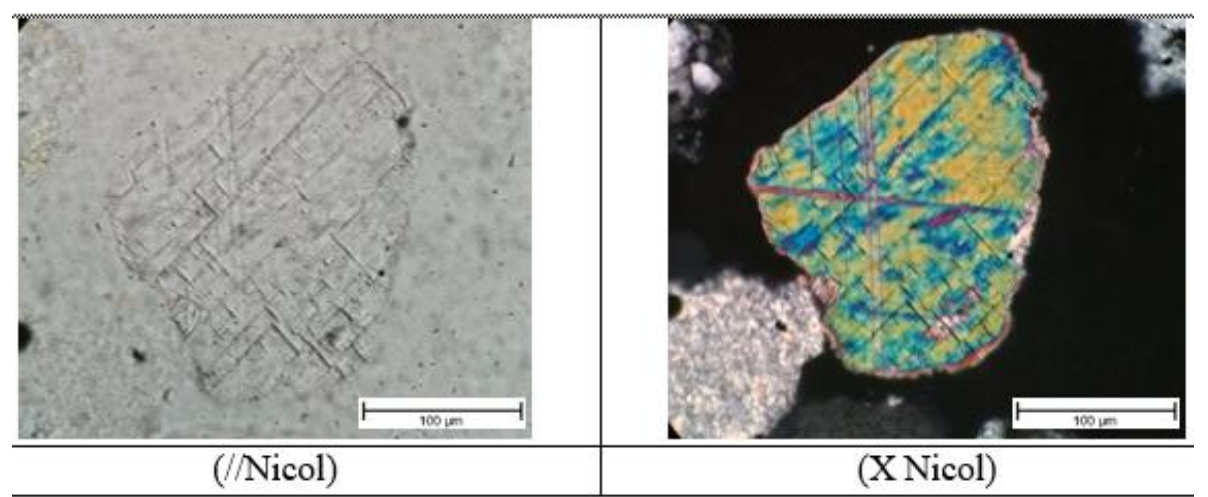

Figure 2. Micrograph of Anhydrite mineral in thin section cutting samples located in the well SH-03 with a depth of 1611-1614 m

\section{Epidote}

Mineral Epidote $\left[\mathrm{Ca}_{2} \mathrm{Al}_{2}\left(\mathrm{Fe}_{3}+\mathrm{Al}\right)\left(\mathrm{SiO}_{4}\right)\right.$ $\left(\mathrm{Si}_{2} \mathrm{O}_{7}\right) \mathrm{O}(\mathrm{OH})$ ] (Figure 3), is formed from hydrothermal fluids with neutral $\mathrm{pH}$, low to moderate $\mathrm{CO} 2$ concentrations. High silica concentrations and moderate $\mathrm{FeO} 2$ concentrations. Epidote itself is formed at temperatures above $240^{\circ} \mathrm{C}$ if present as an alteration of mineral alteration. It can also be formed at temperatures of $270^{\circ} \mathrm{C}$ if it is present as a vein mineral [11].

Epidote formation temperature was 240$340^{\circ} \mathrm{C}$ [10]. The mineral associated with epidote, in general, is quartz $[3,12]$. However, chlorite, illite, calcite, anhydrite, and adularia can also be found as epidote mineral associations. 


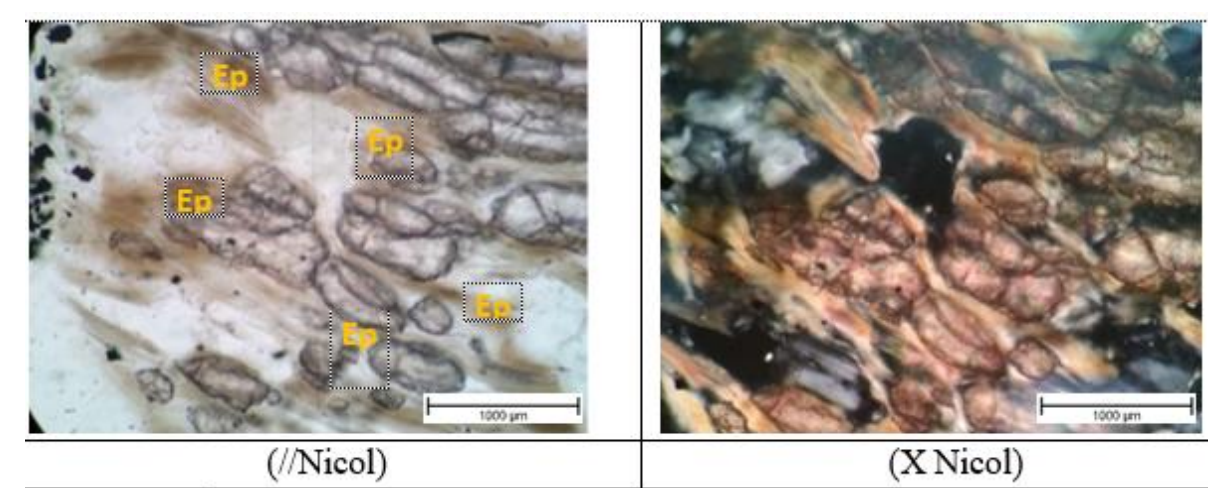

Figure 3. Micrograph of Epidote mineral in thin section cutting samples in the well SH-03 with a depth of 936$939 \mathrm{~m}$.

\section{Calcite}

Mineral Calcite [CaCO3] (Figure 4) is formed from hydrothermal fluids with a neutral-to-neutral $\mathrm{pH}$ approaching acid [8] and fluid with alkaline type $\mathrm{pH}$. The fluid that forms the mineral calcite has various temperatures. Calcite can be formed at low temperatures, below $1000^{\circ} \mathrm{C}$, to high temperatures, above $300^{\circ} \mathrm{C}$. Upon formation, calcite (Figure 4) is generally associated with quartz and illite formation [12]. Calcite can be converted into epidote, actinolite, anhydrite, and quartz [13].

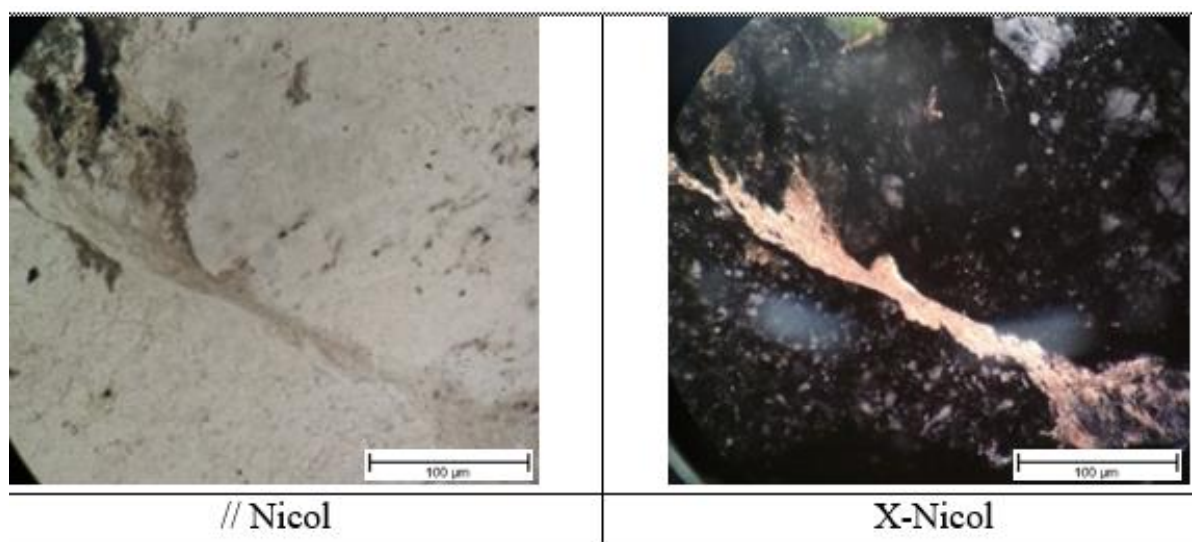

Figure 4. Micrograph of calcite veins in thin section cutting samples located at well SH-01 with a depth of 1054$1057 \mathrm{~m}$.

\section{Chlorite}

Chlorite minerals $\left[\left(\mathrm{Mg}, \mathrm{Fe}^{+2}, \mathrm{Fe}^{+3}\right)_{6}\right.$ $\left.\mathrm{AlSi}_{3} \mathrm{O}_{10}(\mathrm{OH})_{8}\right]$ (Figure 5) are formed in environments with neutral $\mathrm{pH}$ (6-7), the formation of chlorite minerals occurs in the oceanic crust down to the subduction zone. Due to the hydrothermal process, amphibole, pyroxene, and mica can be converted into chlorite. Minerals are generally associated with low sulfidation mineralization. In the observation of the parallel nicol thin incision (Figure 5), the chlorite mineral is columnar. It is turquoise with color interference order I.

Chlorite is formed at temperatures around 120 to $340^{\circ} \mathrm{C}$. Chlorite minerals most often form in rocky environments where the minerals are affected by heat, pressure, and chemical activity. In general, it has temperatures above $300^{\circ} \mathrm{C}$ and is several kilometers below the earth's surface. 


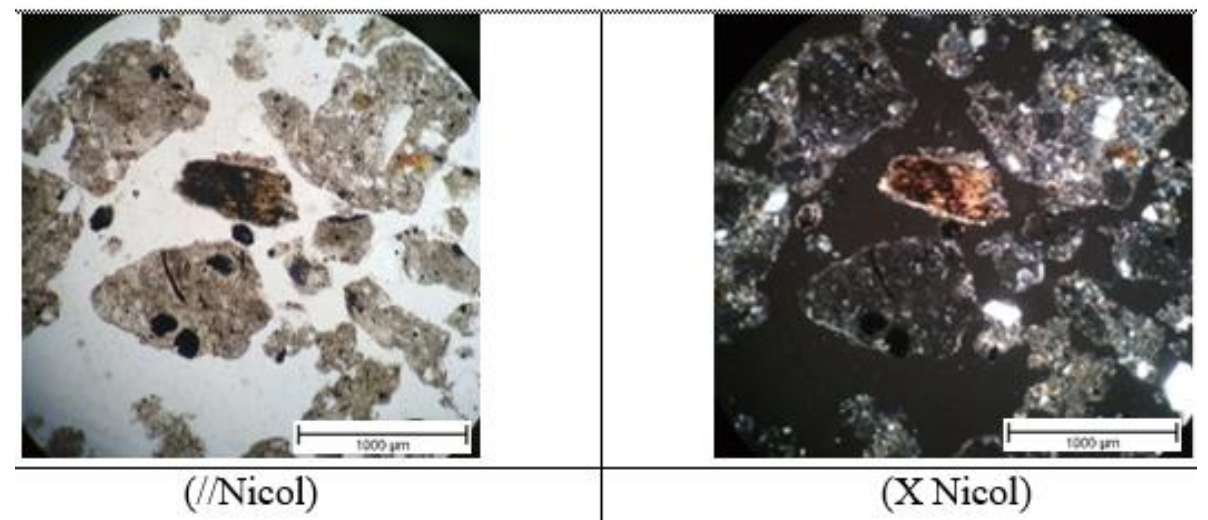

Figure 5. Micrograph of chloride minerals in thin section cutting samples in the SH-03 well with a depth of 333$336 \mathrm{~m}$.

\section{Muscovite}

Muscovite is $\left[\mathrm{K}_{2} \mathrm{Al}_{4}\left(\mathrm{Si}_{6} \mathrm{Al}_{2} \mathrm{O}_{20}\right)(\mathrm{OH}, \mathrm{F})_{4}\right]$ (Figure 6) is the most common mineral of the Mica group, usually found as crystals of considerable size in scaly grains as an element of many rock types. Muscovite has a pearl luster with a perfect one slit, and it looks shiny on X-nicol's observation (Figure 6). Muscovite minerals are formed at temperatures of 180 to $320^{\circ} \mathrm{C}$, and can form a continuous series with celadonite and aluminoceladonite, known as the phengite variety, and found to be associated with illite.

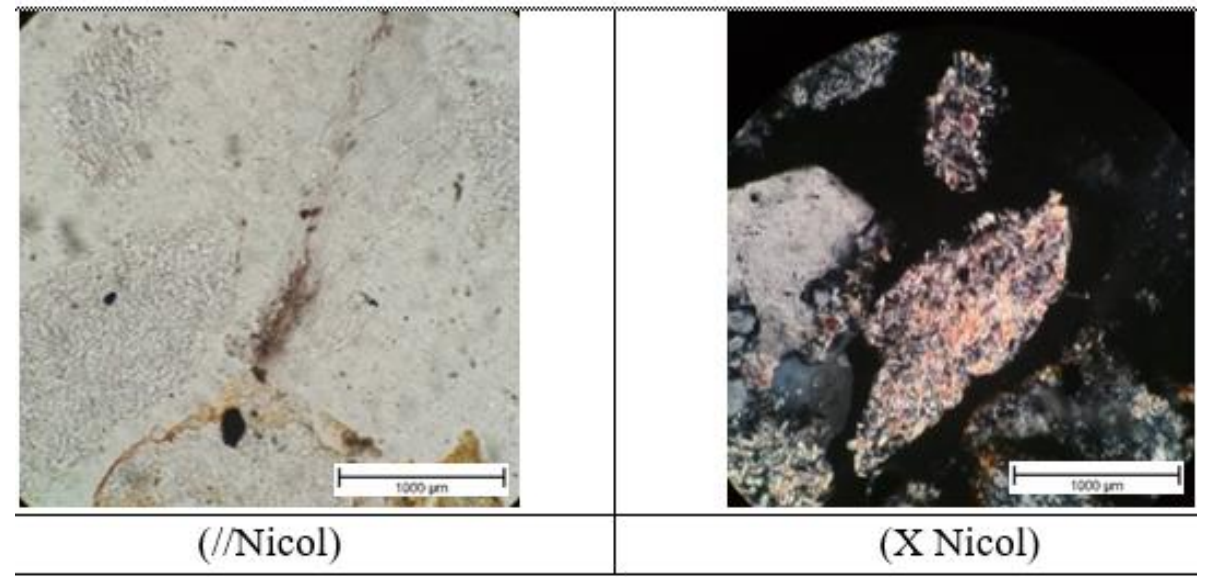

Figure 6. Micrograph of muscovite minerals in thin section cutting samples in the SH-03 well with a depth of 333-336 mku

\section{Pyrophyllite}

Pyrophyllite $\left[\mathrm{SiO}_{4}\right]$ (Figure 7) has two silicate layers known as the gybsite layer. The layer can be formed from consolidated aluminum minerals with clusters in planar triangles with three hydroxides. The overall structure of the pyrophyllite minerals can be shown as layers composed of one another. Pyrophyllite is a mineral formed at temperatures of $80-300^{\circ} \mathrm{C}$.
Pyrophyllite has an isomorph form with a high elemental content of $\mathrm{Mg}$ but not aluminum. In petrographic observations (Figure 7), pyrophyllite was found with a flat, fibrous shape and tricycle texture. The colors in the (parallel nicol) state are colorlesswhite, with the interference colors (cross nicol) pink, light green and blue (Figure 7). 


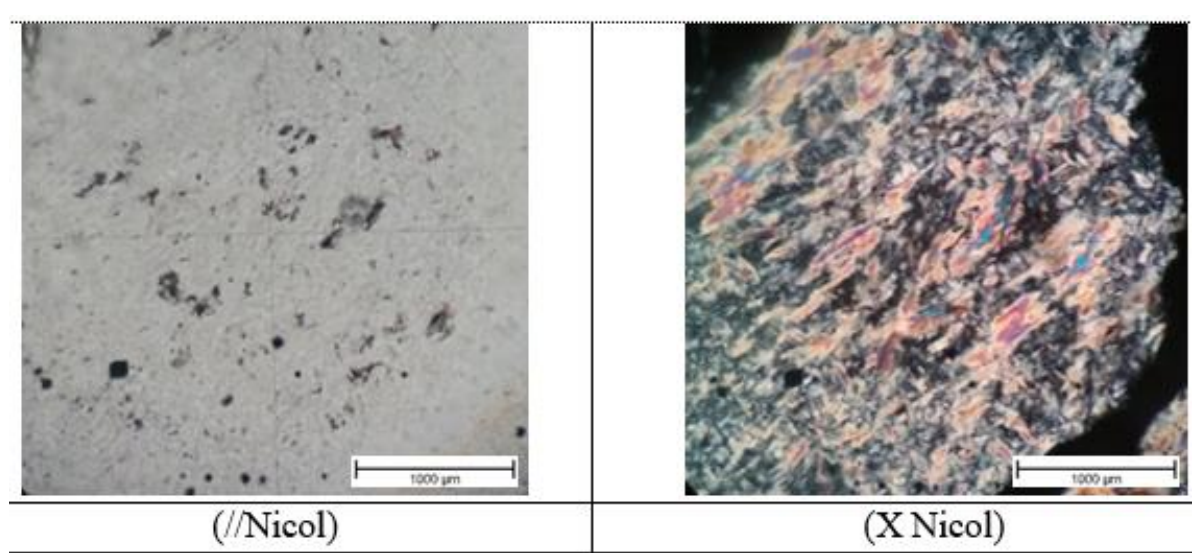

Figure 7. Micrograph of pyrophyllite minerals in thin section cutting samples in the SH-01 well with a depth of $807-810 \mathrm{~m}$.

\section{Zeolite}

Zeolite $\left[\mathrm{Na}_{2} \mathrm{Al}_{2} \mathrm{Si}_{3} \mathrm{O}_{10}\right]$ (Figure 8 ) is a crystalline substance with a structure characterized by an interlocking tetrahedral framework, each consisting of four $\mathrm{O}$ atoms surrounding a cation. This mineral skeleton contains open cavities in the form of channels and tabulates. It is generally occupied by $\mathrm{H} 2 \mathrm{O}$ molecules and exchangeable extra skeletal cations. Zeolites are formed at a temperature of 160 to $240^{\circ} \mathrm{C}$.

Its veins are large enough to allow pathways for further alteration of minerals. The dehydration phase occurs at temperatures mostly below $200^{\circ} \mathrm{C}$ and mostly reversible. The mineral skeleton can be disturbed by the elemental groups of $(\mathrm{OH}$ and $\mathrm{F})$, both of which occupy the tetrahedrons' tops that are not shared by adjacent tetrahedrons.

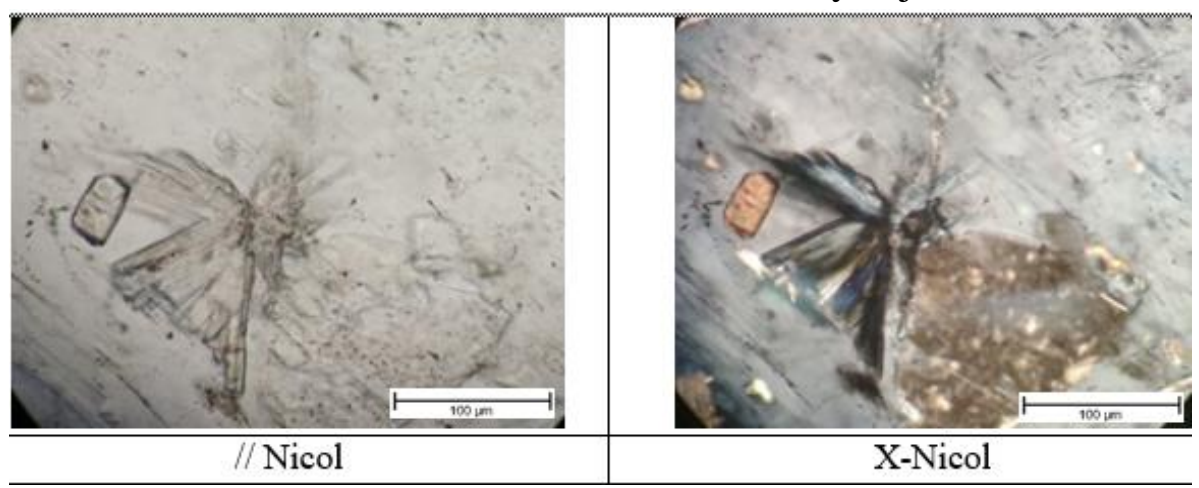

Figure 8. Micrograph of zeolite minerals in thin section cutting sample in the SH-03 well with a depth of 333-336 $\mathrm{mku}$

\section{Geothermal Water Chemical Analysis}

Chemical data of geothermal surface water manifestations were obtained from 13 different points, codes as SHM01 to SHM38. Before the data is processed further, the first analysis carried out is to control the quality of the laboratory data by calculating the ion balance of each manifestation sample and the production well of the Sorik Marapi field.
The ideal ion balance value is $>5 \%$ [3], so it can be used for subsequent analyzes.

The ion balance calculation results show that the samples from production wells show optimal results for the purposes of further analysis, namely SH-01 with $4.63 \%$, SH-02 with $4.89 \%$, and SH-03 with $4.9 \%$ (Table 1 ).

The surface manifestation data can be analyzed through ion-balance equations, only 
the manifestations of SHM01, SHM05, SHM06, SHM10, SHM13, SHM19, SHM32, SHM33, SHM34, SHM35, SHM36, SHM37, and SHM38. They cannot be analyzed for other manifestations because there is no data on the elemental content of bicarbonate $\left(\mathrm{HCO}_{3}\right)$. The calculation of the ion balance of the 13 points of geothermal surface manifestations showed quite good results with an ion-balance value of $5.18 \%-7.18 \%$ for the types of manifestations, namely warm spring and hot spring.

Table 1. Calculation of Ion Balance in production wells in the study area

\begin{tabular}{crrr}
\hline Well & SH-01 & SH-02 & SH-03 \\
\hline Na & 12420 & 11201 & 10994 \\
K & 724.5 & 779.7 & 602.37 \\
$\mathbf{C a}$ & 117 & 178.2 & 190.4 \\
$\mathbf{M g}$ & 0.23085 & 0.1215 & 0.1215 \\
$\mathbf{L i}$ & 114.563 & 100.096 & 80.546 \\
& anion & & \\
$\mathbf{C l}$ & 29074.5 & 27477 & 24140 \\
SO$_{4}$ & 3518.4 & 2001.6 & 4041.6 \\
HCO3- $_{3}$ & 3873.5 & 6222 & 6466 \\
\hline Ion Balance (\%) & $\mathbf{4 , 6 3}$ & $\mathbf{4 , 8 9}$ & $\mathbf{4 , 9}$ \\
\hline
\end{tabular}

\section{Determination of Type and Origin of Fluid}

In determining the fluid type characteristics of a reservoir, $\mathrm{SO}_{4}-\mathrm{HCO}_{3}-\mathrm{Cl}$ Geoindicators are used. Ternary diagram $\mathrm{SO}_{4}-\mathrm{HCO}_{3}-\mathrm{Cl}$ [14] (Figure 9) is a method with the relative content of elements which parameters use chloride $(\mathrm{Cl})$, bicarbonate $\left(\mathrm{HCO}_{3}\right)$, and sulfate $\left(\mathrm{SO}_{4}\right)$ content. The plot points' location shows the type of water that comes out on the surface manifestations and production wells and provides further calculations [15]. The type of water in the research area is divided into chloride water, sulfate water, sulfate chloride water, and bicarbonate water.

Based on the results of the Na-Mg-K ternary diagram plotting data (Figure 10), geothermal water in the research areas is divided into two zones, namely: immature waters zone and mixed waters zone. The type of water that can be used in geothermal calculations is water that enters the equilibrated zone. Because this type of water has reached the equilibrium point, it is stable for reservoir temperature calculations [12], while water that has not entered this zone will still pass the equilibrium point so that its condition currently is a state not yet balanced [11].

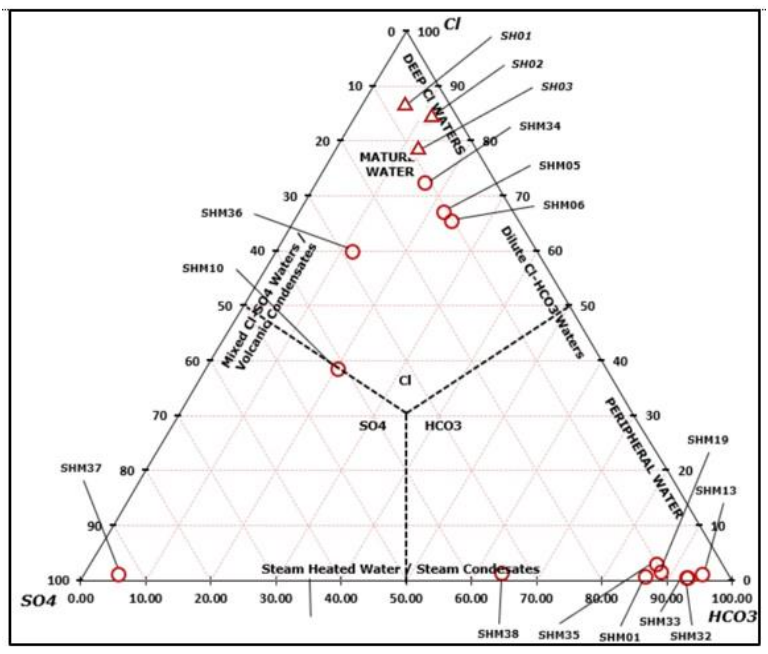

Figure 9. $\mathrm{Cl}-\mathrm{SO}_{4}-\mathrm{HCO}_{3}$ ternary diagram is used to determine the characteristics of geothermal water types, including chloride water, sulfate water, sulfatechloride water, and bicarbonate water [14].

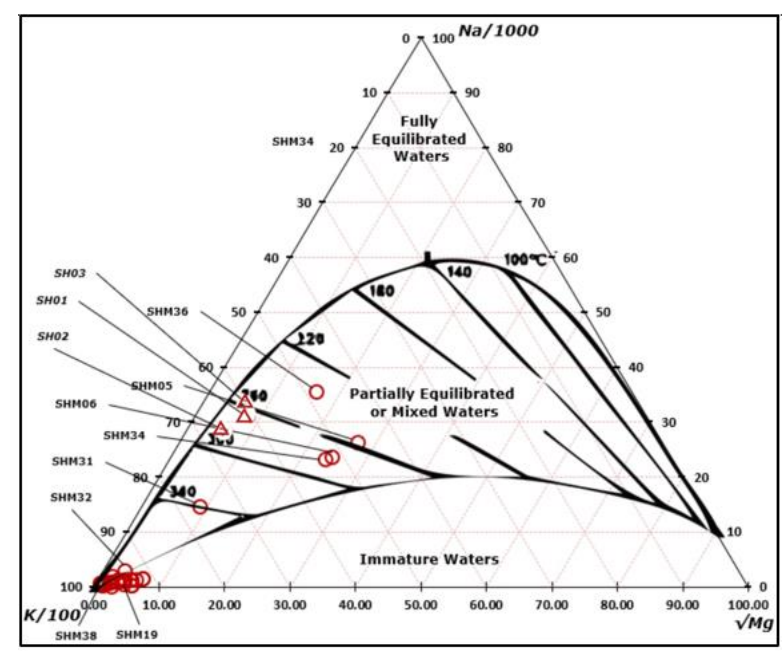

Figure 10. Na-Mg-K ternary diagram is used to determine the characteristics of geothermal water with various types: (fully equilibrated/mixed waters / immature water) [14]. 


\section{Determination of Rock Types}

The Cl-Li-B ternary diagram is used in determining the origin of fluid and reservoir acidity (Figure 11), but its use is limited to fields with water chloride type manifestations. In the research area, there are surface manifestations with the type of chloride water, namely located at the hot springs SHM05, SHM06, and SHM34. The plotting data shows that the three surface manifestations belong to the type of fluid with a low absorption ratio of $\mathrm{B} / \mathrm{Cl}$, meaning that the manifestation fluid has interacted with the basaltic rock type.

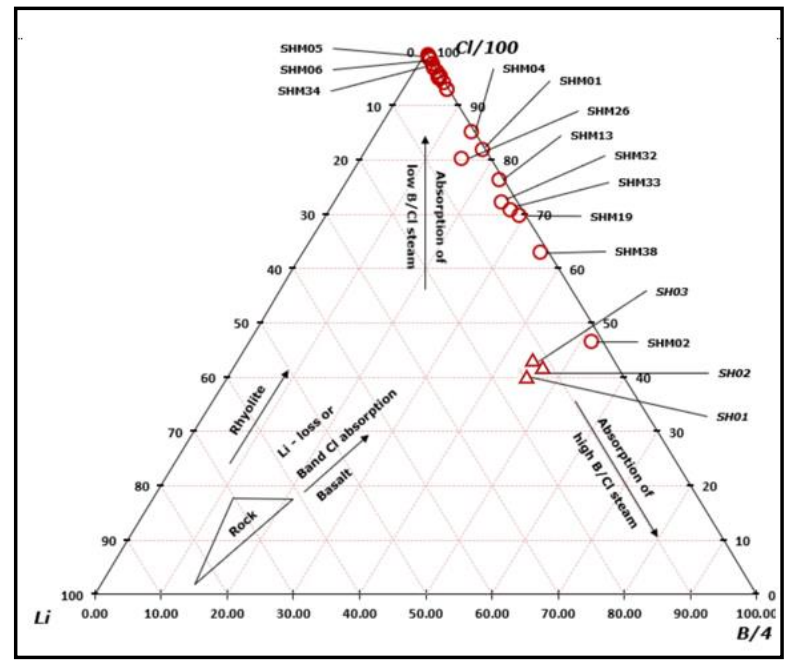

Figure 11. Cl-Li-B ternary diagram is used to determine the fluid origin, reservoir acidity and is used to determine the type of fluid with the absorption ratio $\mathrm{B} / \mathrm{Cl}[14]$.

\section{Gas Contaminant Analysis}

Comparison of nitrogen and argon concentrations, which are the constituent elements of atmospheric air, can indicate air contamination from atmospheric gases entering through rainwater [16]. The small ammonia $\left(\mathrm{NH}_{3}\right)$ value in each production well and several manifestations such as SHM14, SHM17, and SHM21 indicate that these manifestations are in the upflow zone. The $\mathrm{N}_{2}-\mathrm{Ar}-\mathrm{CO}_{2}$ ternary diagram shows the gas in the $\mathrm{SH}-03$ well is close to the air contamination value, while the gas manifestation data shows the gas comes from the magmatic system.

\section{Silica Geothermometer}

Silica geothermometer is produced from the solubility results of various silica types in fluids derived from geothermal fluids with temperature values that can be determined by experiment or experiment. The dissolution of silica in water is based on the following chemical reactions:

$$
\mathrm{SiO}_{2}(\mathrm{~s})+{ }_{2} \mathrm{H}_{2} \mathrm{O} \rightarrow \mathrm{H}_{4} \mathrm{SiO}_{4}
$$

Silica geo-thermometers are generally ideal for use at reservoir temperatures $>150^{\circ} \mathrm{C}$ because, for temperatures below $150^{\circ} \mathrm{C}$, the silica content is controlled by chalcedony. The silica geothermometers' temperature limit is around $250^{\circ} \mathrm{C}$ because above that temperature, the silica will dissolve and evaporate quickly [16]. Because based on the mineral geothermometer, the reservoir's temperature is predicted to be in the range of 150 to $250^{\circ} \mathrm{C}$. Two geothermal equations are used, namely quartz no steam loss and quartz max steam loss (Table 2). So that the following results are obtained:

Table 2. Calculation of the Silica Geothermometer (no steam loss \& steam loss) in the production wells of the study area

\begin{tabular}{cccc}
\hline \multirow{2}{*}{ Geothermometer } & \multicolumn{3}{c}{ Temperature $\left({ }^{\circ} \mathbf{C}\right)$} \\
\cline { 2 - 4 } & SH-01 & SH-02 & SH-03 \\
\hline $\begin{array}{c}\text { Quartz-no } \\
\text { steam loss }\end{array}$ & 273.28 & 284.05 & 259.46 \\
$\begin{array}{c}\text { Quartz-max } \\
\text { steam loss }\end{array}$ & 241.7 & 249.89 & 231.09 \\
\hline
\end{tabular}

From all the geothermometer calculations used, it can be interpreted that the SH-01 well has a temperature range of $241.7^{\circ} \mathrm{C}$ to $279.65^{\circ} \mathrm{C}$, the $\mathrm{SH}-02$ well has a temperature ranging from $249.89^{\circ} \mathrm{C}$ to $302.92^{\circ} \mathrm{C}$ while the well temperature value is $\mathrm{SH} 03$ is $231.09^{\circ} \mathrm{C}$ 
to $271.86^{\circ} \mathrm{C}$. with this temperature value indicates that the research area has a hightemperature geothermal system.

\section{Mineral Alteration and Geochemistry} Correlation

Correlation analysis of alteration minerals and geothermal geochemistry is based on the analysis of alteration minerals at each measuring depth, validated by geochemical data. Geochemical data for the study's geothermal area refers to two aspects, namely geochemical data on surface manifestations and geochemical data for wells SH-01, SH-02, and SH-03.

Alteration study on well SH-01 is divided into three alteration zones: calcite zone, transition zone, and epidote zone. The division of this zone is based on the abundance of its alteration minerals. The calcite zone is at a depth of $277-772 \mathrm{~m}$, with a temperature of 140 to $160^{\circ} \mathrm{C}$. At a depth of 775-884 $\mathrm{m}$, it is a transition zone with temperatures around $180^{\circ} \mathrm{C}$. Whereas at a depth of 847-1054 $\mathrm{m}$, it is an epidote zone with a temperature of 240 to $280^{\circ} \mathrm{C}$.

Alteration studies in the $\mathrm{SH}-02$ well are divided into three alteration zones: the zeolite zone, the transition zone, and the anhydritesericite zone. The division of this zone is based on the abundance of its alteration minerals. The zeolite zone is at a depth of 333-807 m, with a temperature of 150 to $180^{\circ} \mathrm{C}$. At a depth of $807-996 \mathrm{~m}$, it is a transition zone with temperatures around $200^{\circ} \mathrm{C}$. Whereas at a depth of $996-1149$, it is an anhydrite-sericite zone with temperatures of 260 to $300^{\circ} \mathrm{C}$.

The alteration study on the $\mathrm{SH}-03$ well was divided into three alteration zones: chlorite/smectite zone, transition zone, and epidote zone. The division of this zone is based on the abundance of its alteration minerals. The chlorite/smectite zone is at a depth of $801-840 \mathrm{~m}$, with a temperature of 150 to $200^{\circ} \mathrm{C}$. At a depth of $939-1611 \mathrm{~m}$, it is a transition zone with temperatures around $210^{\circ} \mathrm{C}$. Meanwhile, at a depth of $1615-2178$ $\mathrm{m}$, it is an epidote zone with temperatures of $240-280^{\circ} \mathrm{C}$.

The temperature determination is based on the alteration mineral geothermometer. The subsurface temperatures obtained and compared show adjacent values, meaning a good correlation between the alteration mineral data and the geochemical fluid in the Sorik Marapi geothermal field.

\section{Geothermal Reservoir Zone}

Reservoir Zone SH-O1

This zone is a zone with high permeability so that it stores and releases geothermal fluids in high intensity. The reservoir is a zone with a high temperature so that the fluid produced is optimal in turning the turbine. Minerals characterize this zone with high temperatures such as epidote, anhydrite, calcite, and chlorite. This zone is located at a depth of 847-1054 m. Based on the estimated temperature of the fluid geothermometer, it shows a temperature of 241.7 to $279.65^{\circ} \mathrm{C}$, while based on the geothermal mineral content, of alteration shows a temperature of 240 to $280^{\circ} \mathrm{C}$.

\section{Reservoir Zone SH-O2}

This zone is a zone with high permeability so that it stores and releases geothermal fluids in high intensity. So that minerals characterize this zone with high temperatures, such as anhydrite-sericite. This zone is located at a depth of 936-1611 m. Based on the estimated temperature of the fluid geothermometer, it shows a temperature 
of 249.89 to $302.92^{\circ} \mathrm{C}$, while based on the geothermometer, the mineral alteration content shows a temperature of 260 to $300^{\circ} \mathrm{C}$. In this zone, the discovery of anhydrite mineral indicates a significant increase in temperature and a high permeability zone.

\section{Reservoir Zone SH-03}

This zone is a zone with high permeability so that it stores and releases geothermal fluids in high intensity. This zone is characterized by minerals with high temperatures such as epidote, anhydrite, sericite. This zone is located at a depth of 807-1149 m. Based on the estimated temperature of the fluid geothermometer, it shows a temperature of 231.09 to $271.86^{\circ} \mathrm{C}$, while based on the geothermometer, the mineral alteration content shows a temperature of 240 to $300^{\circ} \mathrm{C}$. The zone anhydrite mineral indicates a significant increase in temperature and a high permeability zone in this finding.

\section{CONCLUSIONS}

Alteration minerals that indicate geothermal areas are anhydrite, epidote, illite, calcite, chlorite, secondary quartz, muscovite, pyrophyllite, and zeolite. The alteration zone is located in the illite zone, zeolite zone, epidote zone, anhydrite-sericite zone. The geochemical characteristics of surface manifestations in the study area are chloride water, sulfate water, sulfate-chloride water, and bicarbonate water. For the three production wells entered into the partial equilibration zone. Estimation of reservoir temperature in research area based on geothermometer fluid and mineral alteration well SH-01: $240-280^{\circ} \mathrm{C}$, well SH-02: 249.89 $302.92^{\circ} \mathrm{C}$, well SH-03: $231.09-300^{\circ} \mathrm{C}$. The relationship between altered minerals and fluid geochemistry is valid, based on the reservoir temperature geothermometer. For further research, geophysical analysis and pressure-temperature analysis from exploration wells are needed. These data can support petrographic and geochemical studies to produce an optimal Sorik Marapi geothermal field's conceptual model.

\section{ACKNOWLEDGMENTS}

PT. KS-ORKA Sorik Marapi Geothermal Power for providing primary data in the form of drilling powder samples (cutting) in the wells $\mathrm{SH}-01$, SH-02, and $\mathrm{SH}-03$, as well as geochemical data on geothermal fluids.

\section{REFERENCES}

1. Direktorat Jenderal EBTKE; Badan Geologi Buku Potensi Panas Bumi; 2017;

2. Huttrer, G.W. Geothermal Power Generation in the World 2015-2020 Update Report. In Proceedings of the World Geothermal Congress; Reykjavik, 2020.

3. Wang, C.; Su, B. Application of Combining Method in Geothermal Exploration. Sci. Technol. Inf. 2012, 31-70.

4. Adityatama, D.W.; Purba, D.P.; Kristianto, B. Integrated ITB International Geothermal Workshop 2018.

5. Hall, R. Indonesia, Geology. Encyclopedia of Islands; Univ. California Press, Berkeley: California, 2009;

6. Rock, N.M.S.; Aldiss, D.T.; Aspden, J.A.; Clarke, M.C.G.; Djunuddin, A.; Kartawa, W.; Whandoyo, R. The Geology of the Lubuksikaping quadrangle, Sumatra, 1:250000; Bandung, 1983;

7. Kerr, P.F. Optical Mineralogy; McGrawwHill Book Co.: New York, 1959; ISBN 0070342105.

8. Streckeisen, A. IUGS IUGS Subcommission on the Systematics of Igneous Rocks. Clasification and nomenclature of volcanic rocks, lamprophyres, carbonatites, and melilite rocks. Recomendation and Suggestions. Neues Jarb. für Mineral. 1978, $143,1-14$.

9. Lukman, S.; Bonte, D.; Daud, Y.; Smit, J.; Beekman, F.; Wees, J.D. Van; Purwanto, W. 
Assessing the Role of Pull-Apart Basins for High-Temperature Geothermal Resources in Transcurrent Tectonic Setting: Sumatra and California Compared. In Proceedings of the European Geothermal Congress; Den Haag, 2019; pp. 1-8.

10. Morrison, K. Important Hydrothermal and Their Significance; Auckland, 1997;

11. Browne, P.R.L. Hydrothermal Alteration in Active Geothermal Fields; 1977;

12. Thompson, A.J.B.; Thompson, J.F.H. Atlas of Alteration: Field and Petrographic Guide to Hydrothermal Alteration Minerals; 1996;

13. Simmons, S.F.; Christenson, B.W. Origins of Calcite in a Boiling Geothermal System. Am. J. Sci. Econ. Geol. 1994, 95, 971-999.
14. Giggenbach, W.F. Chemical Techniques in Geothermal Exploration. In Application of Geochemistry in Geothermal Reservoir Development; D’Amore, F., Ed.; UNITAR, 1991; pp. 119-144.

15. Harrison Hot Springs Classification Available online: https://www.geocaching.com/geocache/GC1 1XT4_harrison-hot-springsearthcache?guid=c6cbb814-b628-4086-b00c6de332c410f9.

16. Herdianita, N.R.; Julinawati, T.; Amorita, I.E. Hydrogeochemistry of Thermal. In Proceedings of the World Geothermal Congress (WGC); Denpasar, 2010. 